\title{
Public debt and economic growth in the European Union. Empirical investigation
}

\author{
PIOTR MISZTAL \\ Department of Economics and Finance \\ Jan Kochanowski University \\ Uniwersytecka-Street 15, 25-406 Kielce \\ POLAND
}

\begin{abstract}
The relatively high sizes of public debts in many of the world's member states have led to frequent debates concerning the influence of public debt on economic growth. Analyzing economic literature it can be seen, that theoretical and empirical considerations on this topic are divided into three main parties. The first part of analyzes is the work of the Keynesians, which emphasizes that the budget deficit as well as the public debt positively affects the economic development of the country, mainly through the impact of the budget expenditure multiplier. The opposite view on budget deficits and public debt is represented by the neoclassical school, who argue that the budget deficit and public debt can have negative impact on economic growth. Conversely, proponents of the Ricardian equivalence concept believe that budget deficits and public debt are neutral for economic growth. These three mentioned above approaches to the budget deficit and public debt problem have led to many debates at home and abroad about the importance of budget deficit and public debt in the process of economic growth and economic development of the country. The main objective of the study is to determine the impact of the foreign debt and home debt on economic activity of the country, based on the example of the 27 member countries of the European Union (without United Kingdom) in the period 20062017. The statistics came from the European Statistical Office (Eurostat) and International Monetary Fund database (World Economic Outlook).
\end{abstract}

Key-Words: public debt, economic growth, foreign debt

Received: August 6, 2021. Revised: November 17, 2020. Accepted: December 3, 2021. Published: January 13, 2021

\section{Introduction}

The issue of the influence of public debt on the economic climate has been and still is one of the issue in the debate among economists. In economic literature concerning relationships between public debt and economic growth of the countries, theoretical and empirical analysis are divided into three main parties.

The first part of analyzes is the work of the Keynesians, which emphasizes that the budget deficit and the public debt have a positive influence on the economic situation in the country, mainly thanks to the budget expenditure multiplier. Representatives of the Keynesian school give opinions demonstrating the existence of so called crowd-in effect of private expenditure on public spending due to budget deficit and public debt caused by expansionary fiscal policy. They further underline that usually the budget deficit and public debt lead to an boost in domestic production, which makes private agents more optimistic about their future economic situation while increasing their investment.

The opposite view on budget deficits and public debt is represented by the neoclassical school, who argue that the budget deficit and public debt have negative effects on economic growth. Representatives of the neoclassical school analyze consumer spending of households throughout their entire life cycle. They argue that the state, by noting the budget deficit, shifts the burden of taxes to future generations, leading to an increase in present consumption. If full employment is assumed, representatives of the neoclassical school argue that higher consumption means a decrease in the size of savings. Interest rates need to re-establish 
equilibrium on the capital market. In turn, higher interest rates lead to a decline of private investment (crowding out of private investments) [1].

Conversely, proponents of the Ricardian equivalence concept believe that budget deficits and public debt are neutral for economic growth. Following this line of reasoning, the current budget deficit resulting from the reduction of taxes has to be balanced in the future, for example by raising taxes, thus keeping interest rates and private investment unchanged. These three mentioned above concepts to have led to many disputes at home and abroad about the impact of budget deficit as well as public debt on economic performance of the country.

Hence, the primary aim of the research is to determine the impact of the level of public debt and the structure of public debt on economic activity of the country on the example of the European Union member countries in the period 2006-2017.

\section{Problem Formulation}

The appearance of a budget deficit means that public debt is rising. But since GDP is also rising, the debt to GDP ratio can changed or stay constant. So, if the ratio of public debt to GDP changes or does not change depends on depends on the growth rate of public debt compared to the rate of economic growth of the country. The constantly growing relation of national debt to GDP is a risk to the country that public debt will fall into the path of uncontrolled growth leading to insolvency. Even if the relation of public debt to GDP does not rise significantly, the relatively high level of public debt to GDP may have serious and negative consequences for the country due to rising debt servicing costs. It is extremely important to understand the reasons for the increase in the ratio of public debt to GDP and to find the optimal size of this relation for the country. Therefore, it is necessary to distinguish between a standard budget deficit and a basic budget deficit. The basic budget deficit, also called as the primary deficit, is equal to the standard budget deficit less costs associated with servicing public debt.

$$
\begin{aligned}
& S B=G+(i \cdot P D)-T \\
& P B=G-T
\end{aligned}
$$

where:

SB - standard budget deficit;

PB - basic budget deficit;

PD- public debt;

$\mathrm{G}$ - government expenditure;

$\mathrm{i}$ - interest of public debt;

$\mathrm{T}$ - government incomes (tax and non-tax).
Therefore, on the basis of the above mentioned expressions it can be presented the ratio of public debt to GDP in the form of the following formula:

$\frac{P D}{G D P}=\left(\frac{G-T}{G D P}\right)+\left(i-\frac{\Delta G D P}{G D P}\right) \cdot\left(\frac{P D}{G D P}\right)$

where:

GDP - gross domestic product.

According to above mentioned formula, the ratio of public debt to GDP is the sum of the ratio of primary budget deficit to GDP and the difference between the interest rate and the growth rate of GDP multiplied by the ratio of government debt to GDP. Hence, the public debt-to-GDP ratio increases when the public debt rate is higher than the GDP growth rate under the conditions of a basic budget deficit. To reduce the ratio of public debt to GDP, there must be a surplus in the basic balance of the state budget (higher income than state expenses), otherwise GDP must grow at a faster rate than the cost of servicing public debt. Currently, the main reasons for the rise in the budget deficit and the resulting public debt are:

a) inadequate synchronization between budgetary expenditures and budgetary receipts;

b) excessively expanded functions of the state;

c) the lack of an optimal relationship between tax revenues that do not slow down economic

d) growth and the size of government spending;

e) unfavorable demographic trends (negative balance of natural growth, aging populations);

f) fiscal interventions under economic recession;

g) excessive public expenditures in relation to the possibility of raising budget revenues.

International integration of financial markets is now increasing the possibilities of financing of sovereign debt in foreign markets. Hence often countries take advantage of this opportunity to take out loans, they issue financial instruments abroad, which results in the increase of foreign debt. Foreign debt generally is defined as the total debt in foreign currencies, which domestic entities (government, commercial banks, businesses, private individuals) have taken abroad. Hence, foreign debt may be in the form of sovereign debt, and then it is part of public debt, or it may be a debt that is levied by private parties. Foreign debt occurs in the form of foreign loans as well as in the form of foreign securities or corporate bonds held by foreign entities.

In the path of liberalization of international capital flows, savings are seeking the most efficient use regardless of location. Foreign creditors are ready to lend funds to domestic entities, because by splitting their savings between the wider range of financial assets than in one country, they diversify 
the risk of fluctuations in income from their investments.

Foreign loans are also called as basic transfers (BT) and are define as a variation between net capital inflows and interest payments on foreign debt.

$$
B T=d D-r D=D(d-r)
$$

where:

BT - basic transfers;

D - total foreign debt;

$\mathrm{d}$ - foreign debt growth rate;

$\mathrm{r}$ - average annual interest rate;

dD - net capital inflow;

$\mathrm{rD}$ - total annual interest payments.

Regarding to the equation (4), basic transfers mean profits for the country if $d>r$ or losses if $d<r$. Generally speaking, if the inflow of foreign loans is associated with an increase in productivity, the rate of return exceeds the average level of interest rate in the country, and basic transfers are positive, then the increase in foreign debt does not have long-term, negative impact on the economic growth in the country. Taking into account changes in foreign debt over time, this situation can be presented in the following form:

$$
\left(D_{t}-D_{t-1}\right)=Y_{t}-r D_{t}-C_{t}-I_{t}-G_{t}
$$

Foreign savings are one of the sources of internal accumulation in economy. In particular, developing countries are characterized by inadequate accumulation of internal capital due to the presence of a kind of vicious circle in these countries associated with low efficiency, low income and low savings. Hence, this state requires technical and financial assistance from highly developed countries to fill this gap in capital resources.

Growing savings and investments in the economy lead to economic growth. It should be noted, however, that economic growth will not appear until capital resources reach a specific level. As capital, investment and production rise, the level of savings also grows. After exceeding a certain level of growth in both capital and savings, sufficient conditions will appear to trigger economic growth. The authors of the so-called double gap theory proves that investment is a function of savings, and therefore in developing countries the level of national savings is insufficient to finance the necessary investments to ensure economic growth. On the other hand, if foreign debt is so large that the sum of internal production, consumption, investment and government expenses is smaller than basic transfers, then this situation leads to a debt crisis (equation 6).

$$
C_{t}+I_{t}+G_{t}-Y_{t}<d D_{t}-r D_{t}
$$

A debt crisis, are also known as a foreign debt crisis, and means a situation in which a country is unable to service its foreign debt. This situation may be temporary, in which case it is referred to as a liquidity crisis, or it may be permanent, in which case it is referred to as a solvency crisis.

High public debt can cause serious problems in the economy. It should be noted here that public debt as such does not have to be detrimental to the economy. Depending on the situation, increasing public debt can increase or decrease prosperity. The absolute amount of public debt is not important in this case, but the share of public debt in relation to gross domestic product is important. So, it is important not to maintain the full financial independence of the state, but to guarantee the financial security of the state, i.e. to maintain the ability of the state to raise cash when it is needed.

As for the results of empirical studies on the impact of public debt (including foreign ones) on economic growth, it has to be stated that in most cases the negative impact of high public debt on growth has been confirmed, while only a small part of the analyzes have revealed no significant relations cause and effect between economic growth and sovereign debt [2].

At the same time it must be stated that government debt cannot be compared with private debt. This applies in particular to future public debt burdens, which are not identical to the tax burden that future generations will incur to finance amortization and interest. The future burden of debt depends in particular on the extent to which private investment is displaced by government spending as a result of borrowing in the public sector and the size of public investment financed by loans.

Given the various reasons and macroeconomic interdependence, there is no specific percentage for the ratio of public debt to GDP that can be defined ex ante as a threshold over which governments should expect deterioration in credit conditions on the capital markets. To worsen the situation in the whole economy. This means that high local currency loans are, for example, much less dangerous than non-residents' foreign currency debt.

Hence, the goal of fiscal policy should be to ensure a balanced public debt, rather than reducing it to zero or to a predetermined absolute level. Balanced debt is affected by various factors. One of them is economic growth. High economic growth automatically reduces the ratio of public debt to GDP, generating higher tax revenues and leading to lower social spending contributes to lower deficits, or even government surpluses. Moreover, if the real interest rate on public debt is permanently lower 
than the real growth rate, then the debt is balanced. On the other hand, if the real interest rate is higher than the real growth rate in the long run, then the primary balance, i.e. the difference between current public income and public expenditure less interest on existing public debt, must show a surplus. Otherwise, the share of interest payments in the public budget will increase and will limit the scope of the public sector.

Some economists, such as Modigliani, point out that growing public debt usually leads to a slowdown in economic development. However, Patillo, Romer and Weil found that low levels of public debt had a positive influence on economic growth, while high levels of debt had a negative impact on the rate of economic growth in the country [3].

Schclarek analyzing 59 developing countries and 24 economically developed countries came to the conclusion that in the case of developing countries there is always a negative and significant relationship between total public debt and economic growth. However, in the case of economically developed countries Schclarek did not find a significant relationship between public debt and economic growth [4].

Ferreira in his analysis of the interdependencies between economic growth and public debt confirmed the presence of a relationship between economic growth per capita and public debt in relation to GDP in the countries belonging to the Organization for Economic Cooperation and Development (OECD) in 1988-2001. Moreover, he stated that this relationship is always two-way [5].

Keho studied the causal relationship between fiscal deficits and economic growth in seven selected West African countries in the 1980s of the 20th century in 1980-2005. The results obtained were inconclusive. It turned out that there is no causal link between the budget deficit and economic growth in three of the analyzed countries. The results of the study also revealed the presence of a two-way negative relationship between budget deficits and economic growth in the three successive countries [6].

In addition, empirical investigation done by Kumar and Woo on highly developed and developing countries, revealed the opposite relationship between initial public debt and economic growth in 1970-2007. The results of their analyzes proved that the rise in the ratio of public debt to GDP by $10 \mathrm{pp}$ was accompanied by a decrease in real GDP per capita of about 0.2 percentage point during one year [7].
It should also be noted that many empirical analyzes carried out in recent years point to the existence of a non-linear connection between public debt and economic growth. Well, the results of these studies indicate that public debt has a positive effect on economic growth, but only to a specific level of debt, beyond which the impact of public debt on the GDP growth rate is negative.

Similar analyzes were performed by Smyth and Hsing, who examined the influence of public debt on economic growth in US in the 1980s and 1990s. These authors assessed the optimal level of public debt for the US economy, i.e. the level of public debt that maximizes economic growth. Their findings suggest that the optimal level of public debt in relation to GDP for the US economy was $38.4 \%$ in the period considered [8].

Similar conclusions were drawn by Elbadawi, Ndulu and Ndung, examining the relationship between public debt and GDP in 26 countries of Sub-Saharan Africa in 1980-1994. They have proved that public debt has a positive influence on economic growth in these countries, but only up to 97\% of GDP [9]. In contrast, Pattillo, Poirson, Ricci, examining 93 developing countries in 19721998, showed a positive impact of public debt on economic growth to only 35-40\% of GDP [10].

Reinhart and Rogoff, in an analysis of 44 economically advanced and developing countries in the last two hundred years, stated that high public debt in relation to GDP (over 90\%) was accompanied by lower economic growth in both developed and developing countries In addition, in the case of developing countries, a relatively high level of external debt in relation to GDP (over 60\%) had a negative impact on economic growth [11].

Cecchetti, Mohanty and Zampolli analyzed the relationship between public debt and economic growth in 18 OECD member countries in the years 1980-2010. It turned out that the dynamics of economic growth was falling when the public debt exceeded the $85 \%$ of GDP threshold [12].

Ahlborn and Schweickert believe that different economic systems in countries with comparable levels of public debt are a major source of heterogeneity in terms of the impact of public debt on growth. In continental countries (the so-called core countries of the European Union) the greater impact of reducing public debt on economic growth is greater than in liberal countries. In liberal (AngloSaxon) economies, public debt has a neutral or positive effect on economic growth. On the other hand, the Nordic (Scandinavian) countries are characterized by a non-linear relationship between public debt and economic growth, with negative 
effects of public debt at debt levels close to $60 \%$ of GDP [13].

In turn, Perasso, analyzing statistics on the twenty most heavily indebted countries in the world economy with an average income level, examined the relationship between economic growth and external debt in 1982-1989. The results of the study showed that the adequately conducted economic policy in the country had a greater impact on investment growth and economic growth in highly indebted countries than the reduction of external debt service obligations [14].

Cunningham analyzed the relationship between the burden of foreign debt and economic growth in 16 countries in 1971-2007. Studies have shown that the growth in the burden of foreign debt in these countries has had a harmful impact on economic development [15].

Cohen analyzed the link between external debt and investment in developing countries in the 1980s. Research has shown that there is a comparatively small impact of the size of foreign debt on the size of investment in these countries. The research also revealed the effect of displacing domestic investments (crowding out effect) by spending on foreign debt servicing [16].

On the other hand, Metwally and Tamaschke analyzed the relationship between the cost of servicing external debt, the inflow of external capital, and economic growth in Algeria, Morocco, and Egypt in the 1972-2002 period using the double and simple least squares method. The results of the research confirmed that the inflow of foreign capital had a considerable impact on the ratio of foreign debt to economic growth [17].

Chowdhury analyzed the correlation between foreign debt and economic growth in Bangladesh, Indonesia, Malaysia, the Philippines, South Korea, Sri Lanka and Thailand during 1988-1970. The outcome of the research revealed the unfavorable impact of foreign debt on the level of the country's exchange rate. However, the impact of external debt on GDP growth in these countries has not been revealed [18].

Fosu studied the relationship between economic growth and foreign debt in sub-Saharan African countries in the period 1986-1990. The study showed that high-debt countries recorded a onepercentage-percent annual decline in GDP growth as a result of the high level of external debt [19].

Deshpande analyzed the connection between foreign debt and investment size in 13 highly indebted countries during the 1991-1971 period using the simple least squares method. Studies have confirmed a negative correlation between the size of external debt and investment in these countries [20].

Karagol studied short-run and long-run interaction between economic growth and external debt servicing expenses in Turkey in the period 1956-1996 using cointegration techniques and the standard production function model. The outcome of the study revealed the negative impact of foreign debt servicing on long-term economic growth. This relationship was as well confirmed by the results of Granger's causality tests [21].

Clements, Bhattarcharya and Nguyen have confirmed the negative impact of foreign debt on economic development as a result of the effect of displacing domestic investment by foreign investment. This situation was due to the fact that the high cost of servicing foreign debt contributed to the decrease in the resources and public investment in the country [22].

Folorunso and Felix (investigated the impact of foreign debt and the costs of servicing it on economic growth in Nigeria and South Africa between 1980 and 2007. The authors of the analysis based on neoclassical model of economic growth and using the classic and double least squares method confirmed the negative impact of foreign debt and its costs on economic growth in all analyzed countries. Moreover, they revealed that the negative impact of foreign debt on economic growth in Nigeria was only occurring when the size of this debt exceeded a certain level [23].

On the other hand, studies conducted by Atique and Malik have revealed a negative relationship between national sovereign debt and economic growth and a similar dependency between external debt and economic growth. Moreover, it turned out that growing foreign debt slowed economic growth to a much greater extent than domestic debt [24].

Due to the fact that so far there has been no theoretical and empirical analyzes on the impact of public debt on economic growth in various phases of the business cycle, it is difficult today to predict clearly the final direction of influence of the level and structure of public debt on economic activity of the country growth and downturn of the economic climate. This effect can be non-linear both in terms of size and the structure of public debt.

Public debt also affects the prices of financial securities. For example, an increase in government defense spending should improve the stock market listings of companies operating in this sector of the economy. Conversely, austerity measures proposed by governments during the sovereign debt crisis could have a negative effect on the stock market. because, as can be expected, the demand in the 
economy will diminish and the profits of businesses will fall.

The size of the public debt and the methods of its financing affect the money supply and the interest rate in the economy. High interest rates mean higher cost of capital for companies, lower profits, and therefore lower share prices.

\section{Public debt and the macroeconomic situation of the country}

Inadequate public debt management can force the country's government to change its current policy direction, as an unfavorable debt structure can suddenly increase debt servicing costs and force the fiscal authorities to cut planned expenditure to meet their commitments. On the other hand, improperly conducted fiscal policy may affect the efficiency of debt management, because tax policy and expenditure policy determine the levels of primary surplus / deficit and the amount of debt necessary to issue. As this level is excessive, investors may demand a higher risk premium and may prevent debt managers from issuing a given debt instrument at a reasonable cost and achieving the target debt structure.

Monetary policy can also limit the activities of the government managing public debt, since exchange rate policy and interest rate policy may limit the value of foreign currency debt and variable interest rate debt. For example, debt managers may be forced to limit the share of long-term debt with a fixed interest rate in the national currency or they may be forced to incur debt at very high costs because investors may expect higher inflation or devaluation of the national currency in the future due to loose monetary policy. In such a situation, investors may prefer indexed debt over inflation rates or short-term interest rates, short-term debt or debt denominated in foreign currencies. In turn, domestic debt with a large share of short-term debt, variable interest rate debt or debt in foreign currency may limit the readiness of the central bank to raise interest rates or devaluation of the national currency, as this can lead to debt crisis.

Monetary policy and fiscal policy are mutually dependent because high and volatile inflation, and therefore real interest rates, can reduce public revenues by slowing down private sector economic activity, and central bank sterilization and quasifiscal deficits can directly increase debt levels. Inadequate budget management and high levels of debt can put monetary policy goals at risk, as they can increase inflation and inflation expectations, and can raise real interest rates and / or weaken the currency, leading to deterioration of financial stability [25].

Fig. 1. Interdependencies between public debt management, fiscal policy and monetary policy

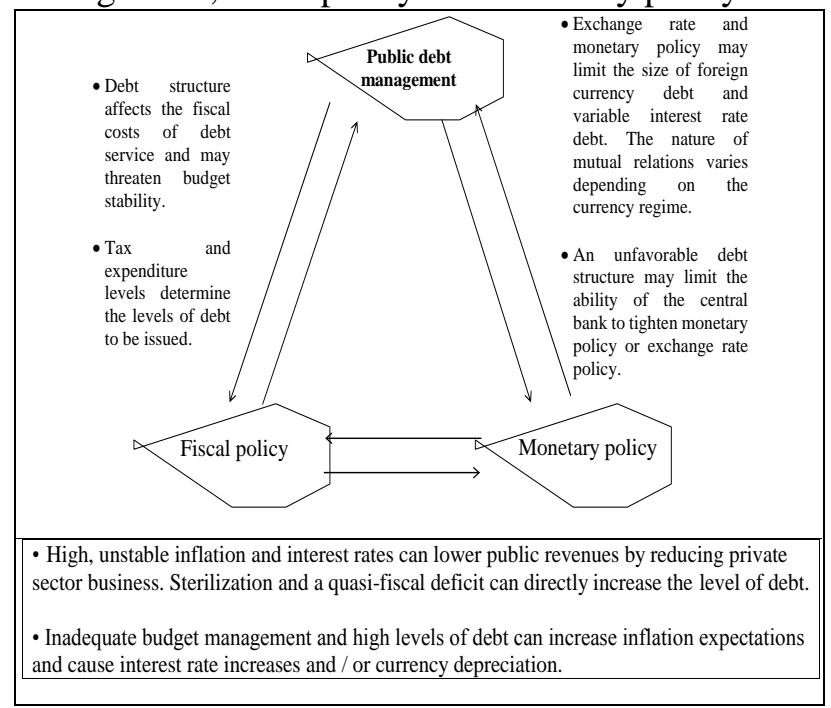

Source: [25].

The country's financial stability can be understood as the stability of financial markets, reflected in the low level of volatility of a number of economic and financial measures, including prices, money supply, credit for the private sector, exchange rate, share prices, bond spreads, interest rates and currency swaps. However, the traditional concept of financial stability focuses on one dimension or price and one characteristic, i.e. low volatility [26].

Houben, Kakes and Schinasi point to three major functions of finance in the contemporary economy that could help build up a wider definition of financial stability. These include promoting effective allocation of real economic resources, facilitating the transformation of maturities to meet the needs of lenders and borrowers, correct pricing and financial risk management [27].

Schinasi made three explanation that can be used to determine financial stability. First, financial stability is a wide concept covering various aspects of financing (infrastructure, institutions and markets). Secondly. financial stability means that resources and risk are effectively allocated and valued and the payment system works efficiently. Thirdly, financial stability concerns not only the lack of financial crises, but also the natural ability of the financial system to avoid, reduce and cope with imbalances that could threaten economic systems or processes [28].

Generally speaking, the existence of a wellfunctioning public debt market facilitates to 
construct and develop effective financial markets. The development of the financial market is an essential element to ensure stable economic growth. A healthy financial market allows for more effective orientation of the country's savings on investments. More effective financial markets also allow long-run loans to individuals and businesses. These loans help increase investment in a more stable system, enabling the financial system to promote effective capital allocation and transformation of maturities. Taking into account their dimension and lower risk in comparison to other domestic issuers, public debt issues are an suitable instrument to facilitate this process. Instruments should be structured to contribute to the development of efficient and liquid financial markets, facilitating the financing of enterprise development in a given economy [29].

Activities and policies implemented by sovereign debt managers can contribute to promoting the development of the financial market and financial stability. Their role has gained a high position in the context of managing the effects of the recent global financial crisis, during which the level of debt in many countries increased significantly in a relatively short time. The increase in the level of debt has increased the pressure on financial markets to meet the higher financial needs of governments, which may threaten the increase in the profitability of debt instruments and the creation of a suboptimal debt structure. The public debt management strategy is therefore an indispensable element of properly run macroeconomic policy, an appropriate political environment and a sound choice of political regime in order to maintain financial stability [30].

\section{Problem Solution}

When analyzing the evolution of public debt in relation to GDP in the European Union in the period 2007-2017, one should notice a systematic increase of this ratio from $57 \%$ in 2007 to about $86 \%$ in 2014 , followed by a systematic decrease in the share of public debt in relation to GDP, until the end of 2017 to just over $81 \%$ (Fig. 2).

Fig. 2. The share of public debt in the GDP of the European Union in the period 2007-2017 [in\%]

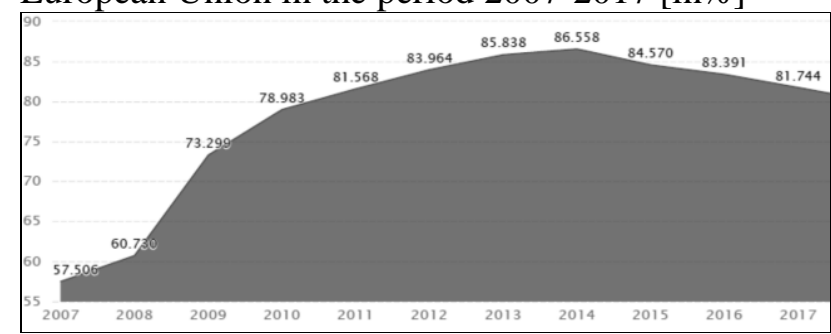

Source: Own calculations.
In turn, in the case of the European Union's external debt in relation to GDP in the period 20072017, generally an upward trend of this indicator can be observed until 2016 with a temporary drop in 2013. On the other hand, in the next year of the audited period, a downward trend was recorded in this respect. The lowest foreign debt in the European Union equal to $111.7 \%$ of GDP was recorded in 2009, while the highest foreign debt of $130.8 \%$ of GDP took place in 2016 (Fig. 3).

Fig. 3. The share of foreign debt in the GDP of the European Union in the period 2007-2017 [in\%]

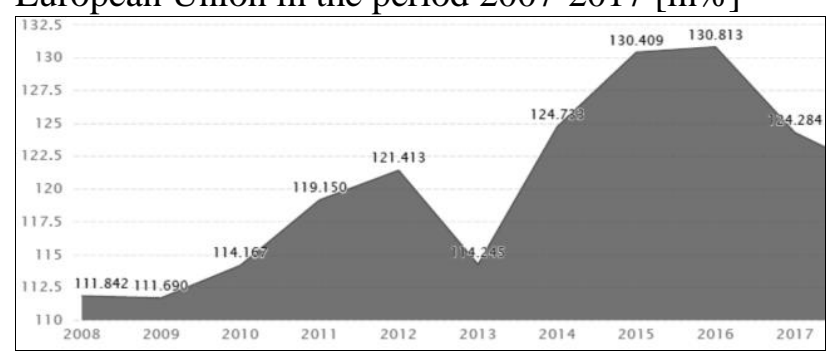

Source: Own calculations.

The comparatively high levels of public debt in many of the world's member states have led to many discussions concerning the influence of public debt on economic growth. In order to examine the cause and effect relationship between GDP changes and structure of public debt in the European Union member countries in the period 2006-2017, the econometric model was estimated based on panel data. Panel data also features cross-sectional data (describing the aggregation at a single moment) and features time series (describing the unit at different times). The purpose of the panel model is to isolate the differences between objects that are inseparable from the specific factors of the individual objects.

$$
Y_{i, t}=a+\alpha_{i} Y_{i, t-1}+\beta_{i} H D_{i, t}+\gamma_{i} F D_{i, t}+\varepsilon_{i, t}(7)
$$

where:

$a$ - free expression equation

$Y$ - dynamic of gross domestic product;

$H D$ - share of domestic debt in GDP,

$F D$ - share of foreign debt in GDP,

$\alpha, \beta, \gamma$ - coefficients of elasticity,

$\varepsilon$ - a random component consisting of purely random parts $\varepsilon_{\mathrm{i}}, \mathrm{t}$ and an individual effect $\mathrm{u}$ and referring to a particular i-th panel unit $\left(v_{i t}=\varepsilon_{i t}+u_{i}\right)$, $i$ - panel unit,

$t$ - analysis period.

All of the time series listed above had quarterly frequency and covered the period from 2006 to 2017. The statistics covered 27 European Union member countries (the EU without United Kingdom) and came from the European Statistical 
Office (Eurostat) and International Monetary Fund database (World Economic Outlook).

The results of the Granger causality test carried out showed in fact that there were significant, oneway relationships between foreign debt and gross domestic product as well as between domestic debt and gross domestic product. Null hypotheses were rejected as regards the lack of foreign debt's impact on GDP and the lack of impact of domestic debt on GDP. On the other hand, the null hypothesis concerning the lack of GDP impact on foreign debt and domestic debt were confirmed (Table 1).

Table 1. Pairwise Granger Causality Tests

\begin{tabular}{|l|c|c|c|}
\hline \multicolumn{1}{|c|}{ Null Hypothesis: } & Obs & $\begin{array}{c}\text { F- } \\
\text { Statistic }\end{array}$ & Prob. \\
\hline FD does not Granger Cause GDP & 270 & 2.41898 & 0.0910 \\
\hline GDP does not Granger Cause FD & 4.23077 & 0.0155 \\
\hline HD does not Granger Cause GDP & 270 & 2.02739 & 0.1337 \\
\hline GDP does not Granger Cause HD & 6.13677 & 0.0025 \\
\hline
\end{tabular}

\section{Lags: 2}

Source: Own calculations.

The model was estimated by means of the ordinary least squares (OLS). In the OLS model, the assumption is that the index $\mathrm{i}=1, \ldots, \mathrm{N}$ denotes consecutive objects, while the index $\mathrm{t}=1, \ldots, \mathrm{T}$ units of time. Estimation using OLS is acceptable when the individual effect is not present and the panel is treated as a set of cross-sectional data (Table 2).

Table 2. Panel Least Squares Estimations

\begin{tabular}{|c|c|c|c|c|}
\hline \multicolumn{5}{|c|}{ Dependent Variable: GDP } \\
\hline Variable & Coefficient & $\begin{array}{l}\text { Std. } \\
\text { Error }\end{array}$ & t-Statistic & Prob. \\
\hline $\mathrm{C}$ & 3.588685 & 0.879116 & 4.082151 & 0.0001 \\
\hline FD & -0.037429 & 0.014383 & -.602371 & 0.0097 \\
\hline HD & -0.033608 & 0.014127 & -.378905 & 0.0180 \\
\hline \multicolumn{5}{|c|}{ Effects Specification } \\
\hline \multicolumn{5}{|c|}{ Cross-section fixed (dummy variables) } \\
\hline \multicolumn{4}{|c|}{ Period fixed (dummy variables) } & \\
\hline R-squared & 0.616445 & Mean dep & endent var & 1.819444 \\
\hline $\begin{array}{c}\text { Adjusted } \\
\text { R-squared }\end{array}$ & 0.563774 & S.D. depe & ndent var & 3.935859 \\
\hline $\begin{array}{c}\text { S.E. of } \\
\text { regression }\end{array}$ & 2.599533 & $\begin{array}{r}\text { Akaik } \\
\text { crite }\end{array}$ & $\begin{array}{l}\text { e info } \\
\text { rion }\end{array}$ & 4.863685 \\
\hline $\begin{array}{l}\text { Sum } \\
\text { squared } \\
\text { resid }\end{array}$ & 1919.150 & Schwarz & criterion & 5.330443 \\
\hline $\begin{array}{c}\text { Log } \\
\text { likelihood }\end{array}$ & -747.9169 & $\begin{array}{r}\text { Hannar } \\
\text { cri }\end{array}$ & $\begin{array}{l}\text { 1-Quinn } \\
\text { ter. }\end{array}$ & 5.049989 \\
\hline F-statistic & 11.70364 & Durbin- $\mathrm{K}$ & atson stat & 1.366312 \\
\hline $\begin{array}{l}\text { Prob(F- } \\
\text { statistic) }\end{array}$ & 0.000000 & & & \\
\hline
\end{tabular}

Source: Own calculations.

On the basis of the above data, it can be stated that in the case of the European Union member countries, there was negative impact of foreign debt and domestic debt on GDP growth. An increase in foreign debt in relation to GDP by 1 percentage point led to a decline in GDP growth by around 0.04 p.p., while an increase in domestic debt in relation to GDP by 1 percentage point led to a drop in the GDP growth rate by 0.03 p.p.

Model statistics such as $\mathrm{R}^{2}$, standard error of residuals and sum of squares of residues, $F$ statistics and Breusch-Pagan, Pesaran scaled, Bias-corrected scaled, Pesaran tests were made with Eviews for model verification (Table 3).

Table 3. Residual Cross-Section Dependence Test

\begin{tabular}{|l|c|c|c|}
\hline \multicolumn{5}{|c|}{$\begin{array}{c}\text { Null hypothesis: No cross-section dependence } \\
\text { (correlation) in residuals }\end{array}$} \\
\hline Test & Statistic & d.f. & Prob. \\
\hline Breusch-Pagan LM & 733.6005 & 351 & 0.0000 \\
\hline Pesaran scaled LM & 14.44033 & & 0.0000 \\
\hline Bias-corrected scaled LM & 13.21305 & & 0.0000 \\
\hline Pesaran CD & -0.108225 & & 0.9138 \\
\hline
\end{tabular}

Source: Own calculations.

All tests carried out with the exception of Pesaran CD test, confirmed the existence of a null hypothesis regarding no cross-section dependence (correlation) in residuals.

\section{Conclusion}

A high public debt can cause serious problems in the economy. It should be noted here that public debt as such does not have to be harmful to the economy. Depending on the situation, growing public debt can increase or decrease prosperity. The absolute amount of public debt is not important in this case, but the share of public debt in relation to gross domestic product is important. Therefore, it is important not to maintain the full financial independence of the state, but to guarantee the financial security of the state, that is, to maintain the ability of the state to obtain cash when the need arises.

As regards the results of empirical studies on the impact of public debt (including foreign debt) on economic growth, it should be noted that in the majority of cases the negative impact of high public debt on economic growth was confirmed, while only a small part of the analyzes did not reveal any significant relations cause and effect between economic growth and sovereign debt. In the case of our analysis, the negative effect of foreign debt and domestic debt on GDP growth was revealed, although the impact was slightly higher in the case of foreign debt. Therefore, the results of the research 
carried out are in line with the results of the analysis carried out by Atique and Malik [24].

At the same time, it should be noted that government debt cannot be compared to private debt. This mainly applies to future liabilities related to public debt, which are not identical to the tax burden that future generations will have to finance depreciation and interest. The future debt burden depends in particular on the extent to which private investments are displaced by government spending as a result of borrowing in the public sector and the size of public investment financed from loans.

Considering the various reasons and interrelationships between macroeconomic factors, it can be concluded that there is no specific percentage in terms of the public debt-to-GDP ratio, which can be defined ex ante as a threshold above which governments should expect deterioration of the conditions for obtaining loans on capital markets and to worsen the situation in the entire economy. This means that high loans in local currency are, for example, much less dangerous than indebtedness to non-residents in a foreign currency.

Hence, the goal of fiscal policy should be to ensure sustainable public debt, not to reduce it to zero or to a predetermined absolute level. Different factors affect a balanced debt. One of them is economic growth. High economic growth automatically reduces the ratio of public debt to GDP, generating higher tax revenues and leading to lower social spending contributes to lower deficits, or even government surpluses. In addition, if the real interest rate on public debt is permanently lower than the real rate of economic growth, then the indebtedness is balanced. In turn, if the real interest rate is higher than the real rate of economic growth in the long run, then the primary balance, i.e. the difference between current public revenues and public expenditure minus interest on the existing public debt, must show a surplus. Otherwise, the share of interest payments in the public budget will raise the scope of the public sector [26].

In some situations, central banks can assist national governments in reducing the problem of high public debt. For example, under the quantitative easing policy, the central banks of many countries, including the European Central Bank, the Federal Reserve System, the Central Bank of Japan purchase securities such as government bonds, which facilitates the financing of public debt. The expansionary monetary policy of the abovementioned central banks also leads to a drop in the interest rate, which results in a lower cost of borrowing by individual countries and easier servicing of public debt.
In the near future, fiscal reforms are planned in the European Union both at the national and EU level in order to reduce the risk in economies with high debt. After the COVID-19 crisis is over, there will be strong pressure for economic recovery in the EU. Consequently, further efforts will be needed to build fiscal buffers in good times and to mitigate fiscal risks over the medium term. An EU resolution fund is currently being negotiated at EU level, which will be one of the important tools to strengthen the foundations for sustainable growth in the wake of the COVID crisis. At the same time, the fund can support heavily indebted countries in pursuing their macroeconomic stabilization. Future research in this area may help find the right way for EU countries to emerge from the problem of rising sovereign debt.

\section{References:}

[1] Dombi Á.. Dedák I. (2019). Public debt and economic growth: what do neoclassical growth models teach us? Applied Economics 51: 1-29.

[2] Rahman H.N.A., Ismail S., Ridzuan A.R. (2019). How does public debt affect economic growth? A systematic review. Cogent Business \& Management 6:1.

[3] Patillo C., Romer D., Weil D. N. (2004). What are the channels through which external debt affects growth?, IMF Working Paper 15: 1-34.

[4] Schclarek A. (2005). Debt and economic growth in developing and industrial countries. Lund University Working Papers 34: 1-40.

[5] Ferreira C. (2009). Public debt and economic growth: a granger causality panel data approach. Technical University of Lisbon Working Papers 24: 1-17.

[6] Keho Y. (2010). Budget deficits and economic growth: causality evidence and policy implications for WAEMU countries. European Journal of Economics, Finance and Administrative Sciences 18: 99-104.

[7] Kumar M. S., Woo J. (2010). Public debt and growth. IMF Working Paper 174: 1-46.

[8] Smyth D. J., Hsing Y. (1995). In search of an optimal debt ratio for economic growth. Contemporary Economic Policy 13(4): 51-59.

[9] Elbadaw I., Ndulu B., Ndung'u N. (1997). Debt overhang and economic growth in Sub-Saharan Africa, in: Z. Iqbal, R. Kanbur. (eds.). External finance for low-income countries, International Monetary Fund. Washington: 49-76.

[10] Pattillo C., Poirson H., Ricci L. (2002). External debt and growth. IMF Working Paper 2(69): 1-49. 
[11] Reinhart C. M., Rogoff K. S. (2010). Growth in a time of debt. NBER Working Paper 15639: 126.

[12] Cecchetti S., Mohanty M. S., Zampolli F. (2011). The Real Effects Of Debt. BIS Working Papers 352: 1-39.

[13] Ahlborn M., Schweickert R. (2015). Public Debt And Economic Growth - Economic Systems Matter. PFH Research Paper 02: 132.

[14] Perasso G. (1992). Debt Reduction versus Appropriate Domestic Policies. Kyklos 45(4): 457-467.

[15] Cunningham R. T. (1993). The Effects of Debt Burden on Economic Growth in Heavily Indebted Nations.Journal of Economic Development 18(1): 115-126.

[16] Cohen D. (1993). Low Investment and Large LCD Debt in the 1980s. The American Economic Review 83(3): 437-439.

[17] Metwally M. M., Tamaschke R. (1994). The interaction among foreign debt, capital flows and growth; case studies. Journal of Policy Modelling 16(6): 597-608.

[18] Chowdhury K. (1994). A structural analysis of external debt and economic growth: some evidence from selected countries in Asia and the Pacific. Applied Economics 26: 1121-1131.

[19] Fosu A. K. (1996). The Impact of External Debt on Economic Growth in Sub-Saharan Africa. Journal of Economic Development 12(1): 61-69.

[20] Deshpande A. (1997). The Debt Overhang and the Disincentive to Invest. Development Economics 52: 169-187.

[21] Karagol E. (2002). The Causality Analysis of External Debt Service and GNP: The Case of Turkey. Central Bank Review 2(1): 39-64.

[22] Clements B., Bhattarcharya R., Nguyen T. Q. (2003). External Debt, Public Investment, and Growth in Low- Income Countries. IMF Working Paper 03/249: 1-25.

[23] Folorunso S. A., Felix O. A. (2008). The Impact of External Debt on Economic Growth: A Comparative Study of Nigeria and South Africa. Journal of Sustainable Development in Africa 10(3): 234-264.

[24] Atique R., Malik K. (2012). Impact of Domestic and External Debt on the Economic Growth of Pakistan. World Applied Sciences Journal 20 (1): 120-129.

[25] Togo E. (2007). Coordinating Public Debt Management with Fiscal and Monetary Policies: An Analytical Framework. The World
Bank Policy Research Working Paper 4369: 337.

[26] Adepoju A. A., Salau A. S., Obayelu A.E. (2007). The Effects of External Debt Management on Sustainable Economic Growth and Development: Lessons from Nigeria. Munich Personal RePEC Achieve Paper 2147: 1-30.

[27] Houben A., Kakes J., Schinasi G. J. (2004). Toward a Framework for Safeguarding Financial Stability. IMF Working Paper 101: 148.

[28] Schinasi G. J. (2004). Defining Financial Stability. IMF Working Paper 187: 1-18.

[29] Das U. S., Papapioannou M., Pedras G., Ahmed F., Surti J. (2010). Managing Public Debt and Its Financial Stability Implications. IMF Working Paper 280: 1-28.

[30] Wolswijk G., de Haan J. (2005). Government Debt Management in the Euro Area Recent Theoretical Developments and Changes In Practices. ECB Occasional Paper Series 25: 128.

\section{Appendix 1. Glossary}

Dummy variable is one that takes only the value 0 or 1 to indicate the absence or presence of some categorical effect that may be expected to shift the outcome.

$R$-squared $\left(R^{2}\right)$ is a statistical measure that represents the proportion of the variance for a dependent variable that is explained by an independent variable or variables in a regression model.

The adjusted $R$-squared is a modified version of Rsquared that accounts for predictors that are not significant in a regression model.

S.E of regression is the summary measure based on the estimated variance of the residuals.

Sum squared resid. implies sum of squared residuals for the model (explained variation) and residuals (unexplained variation).

Log likelihood is the difference between the log likelihood values of the restricted and unrestricted versions of the model.

$F$-statistic captures whether the explanatory variable is significant in explaining the outcome variable. The higher the F-stat, the better for the model.

Prob (F-statistic) is the probability value of 0.0000 is the probability value that indicates the statistical significance of the F statistic. Usually, it is preferred to have a prob-value that is less than 0.05 .

Akaike/Schwartz/Hannan-Quinn info criteria are often used to choose between competing models.

Creative Commons Attribution License 4.0 (Attribution 4.0 International, CC BY 4.0)

This article is published under the terms of the Creative Commons Attribution License 4.0

https://creativecommons.org/licenses/by/4.0/deed.en_US 